\title{
The dynamic impact of external shocks on fiscal reaction function in a small open economy
}

\author{
Che Loong Lee ${ }^{1,2, *}$ \\ ${ }^{1}$ Center of Sustainability and Inclusive Development (SID), Universiti Kebangsaan Malaysia, Malaysia \\ ${ }^{2}$ Centre for Accounting, Banking and Finance (CABF), Universiti Tunku Abdul Rahman, Malaysia
}

Received: 2 October 2019

Revised: 15 November 2019

Accepted: 19 November 2019

\begin{abstract}
Fiscal authorities in a small open economy should utilize its fiscal instrument feedback to external shocks. This paper analyzes the dynamic respond of budgetary policy to external shocks in Malaysia by a Structural VAR model. On the one hand, the results confirm that external shocks have a significant effect on fiscal reaction function variables. On the other hand, the direct consideration of budgetary reaction of Malaysia to external shocks is limited. Therefore, fiscal authorities should enhance its feedback to external shocks to achieve stable and sustain growth.

Keywords: external shocks; fiscal reaction function; Malaysia; structural VAR; small open economy

JEL Classification Codes: E62, F34, C22
\end{abstract}

\section{Introduction}

Fiscal reaction function (hereafter, FRF) is the most widely used empirical test for examining fiscal sustainability and output stability. FRF pioneered by Bohn (1998) has proven it as a robust specification for testing fiscal sustainability (See Bohn, 2007). Furthermore, Mendoza and Ostry (2008) improve FRF by embark output gap for output stability testing. FRF has been discuss extensively by latest literature ${ }^{1}$. However, there has been little quantitative analysis of the impact of external shocks on FRF.

As a small open economy, the fiscal policy of Malaysia is vulnerable to external shocks. On the one hands, the United States (hereafter, US) was one of the largest export destinations of Malaysia consist of $32 \%$ in 2018. On the other hands, the government revenue of Malaysia over-reliance on oil wealth (exceeding $20 \%$ in 2007-2018). Thus, it expected that any changes in US stock market, US interest rate and crude oil price would transmit to the output gap and public debt. Therefore, the fiscal authorities will adjust their budget balance to stabilize the fluctuation of the output and maintain fiscal sustainability.

\footnotetext{
*E-mail: lcloong@utar.edu.my.
}

Citation: Lee, C. L. (2020) The dynamic impact of external shocks on fiscal reaction function in a small open economy, Economics and Business Letters, 9(2), 84-49.

DOI: 10.17811/ebl.9.2.2020.84-89

${ }^{1}$ e.g. De Mello (2008), Plödt \& Reicher, (2015), Baharumshah et al. (2017), Aldama \& Creel, (2019). 
Figure 1. The trend of primary balance and external shocks (Malaysia, 1996Q1-2018Q4).

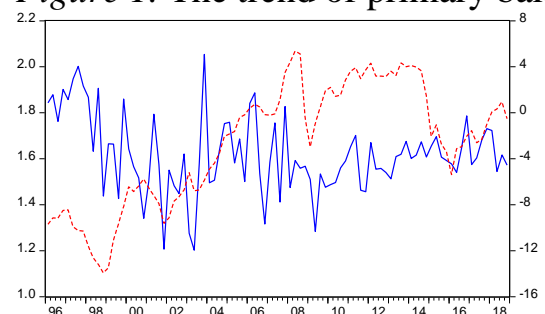

- Seasonally adjusted primary balance over GDP
--- Seasonally adjuted log West Texas Intermediate crude oil price

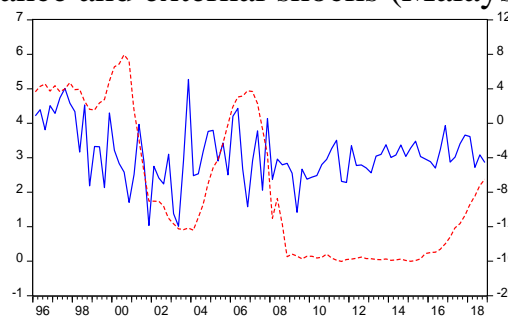

- Seasonally adjusted primary balance over GDP
--- Seasonally adjusted US 3 months treasury bill rate

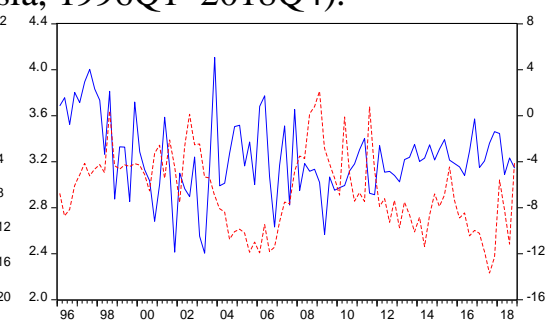

- Seasonally adjusted primary balance over GDP
--- Seasonally adjused the log CBOE Volatility Index

Note: The external shocks in the left panel, centre panel and right panel are crude oil price, real US interest rate and volatility of the US stock market, respectively. Source: Author compilation.

Malaysia's fiscal adjustment to external shocks has been impressive. Figure 1 shows that the fiscal reaction of Malaysia to external shocks. The left panel displays the fluctuation of primary balance is high during the upswing of crude oil price then turn to the stable when crude oil price stable. Furthermore, the trend of primary balance is similar to the US real interest rate and stock market risk, which show in the centre and right panel, respectively. Motivated by this evidence, this paper tries to bridge the gap between fiscal reaction function and external shocks.

A large body of evidence finds that adverse external shocks have significant negative impacts on short- and medium-run growth through their effects on macroeconomic fluctuation, unemployment dynamics, and monetary policy ${ }^{2}$. However, far too little attention has been paid on the impact of external shocks to fiscal policy. A few studies report that US interest rate is positively related to the probability of default in emerging market (Banerji et al., 2014; Weigel and Gemmil, 2006). What is not yet clear is the fiscal reaction in emerging market to change of US interest rate.

In the new global economy, external shocks become a central issue for fiscal authority in emerging market. The aim of this study is to shine new light on FRF through an examination the impact of external shocks on fiscal instruments. In achieving this objective, this paper employs a Structural Vector Autoregressive (hereafter, SVAR) Model in non-recursive form to investigate the dynamic reaction of fiscal instrument to external shocks.

This paper is structured as follows. Section 2 focuses on the data and methodology. The empirical results present in Section 3. Section 4 concludes and policy implication.

\section{Methodology}

\subsection{Fiscal reaction function}

$$
p b_{t}=\delta+\rho p d_{t}++\alpha_{Y} Y V A R_{t}+\alpha_{G} G V A R_{t}+\varepsilon_{t}
$$

for $t=1, \ldots, N$, where $d$ denote lagged central government debt (also name public debt) over GDP, $b$ is primary balance over GDP, $\delta$ is an intercept, YVAR and GVAR are proxies for temporary fluctuations in output and government expenditures and $\varepsilon_{t}$ is i.i.d. Formally, for $\rho>$ 0 , which in turn implies that the governments do not use new debt to finance old debt and thus the fiscal sustainability hold ${ }^{3}$.

According to Mendoza and Ostry (2008), YVAR obtained by using Hodrick-Prescott to detrend the data with a smoothing parameter set at 1600 , and this the corresponding formula is:

$$
Y V A R=\frac{R G D P_{t}-R G D P_{t}^{T}}{R G D P_{t}}
$$

In these expressions, a superscript $T$ denotes the trend value of the corresponding variable.

\footnotetext{
2 (see Uribe and Yue, 2006; Akınc1,2013; Epstein et al., 2019; Horvath and Zhong, 2019)

3 (see Bohn, 1998; De Mello, 2008; Plödt \& Reicher, 2015; Baharumshah et al., 2017; Aldama and Creel, 2019).
} 


\subsection{SVAR identification}

This paper analyzes the transmission of structural shock from the external shocks to FRF in Malaysia within a two-blocks SVAR. A typical representation of the SVAR is;

$$
B_{0} y_{t}=B(L) y_{t-p}+\varepsilon_{t}
$$

where $B(L)$ is an autoregressive lag-polynomia, and $\varepsilon_{t}$ is the vector of structural innovations. The vector $y_{t}=\left[D^{E}, R^{E}, V^{E}, Y V A R, P D, P B\right]$ includes all the endogenous variables in our model and relies on two blocks: the first one refers to "external" variables (US), whereas the second one includes "domestic" fiscal variables (Malaysia). The external block of variables consist of a measure of external demand, $D^{E}$, proxy by crude oil price benchmark West Texas intermediate; a measure of external real interest rate (risk-free), $R^{E}$, proxy by the 3-month gross US Treasury bill rate; and a measure of external uncertainly, $U^{E}$, proxy by VIX index, which can be interpreted as the risk of the US stock market. Domestic block includes output gap $(Y V A R)$, public debt $(P D)$ and primary balance $(P B)$ which highlighted in FRF. This paper follows Hachula and Nautz (2018) consider a SVAR in levels in order to allow for both stationary and non-stationary fiscal reaction.

After imposing the appropriate orthogonalization of structural disturbance restrictions, Eq. (2) becomes:

$$
B_{0} y_{t} \equiv\left[\begin{array}{cccccc}
1 & 0 & 0 & 0 & 0 & 0 \\
B_{21} & 1 & 0 & 0 & 0 & 0 \\
B_{31} & B_{32} & 1 & 0 & 0 & 0 \\
B_{41} & B_{42} & B_{43} & 1 & 0 & 0 \\
0 & B_{52} & 0 & B_{54} & 1 & 0 \\
B_{61} & 0 & 0 & B_{64} & B_{65} & 1
\end{array}\right]\left[\begin{array}{c}
D^{E} \\
R^{E} \\
U^{E} \\
Y V A R \\
P D \\
P B
\end{array}\right]
$$

The coefficient $\beta_{i j}$ indicates how variable $j$ affects variable $i$, contemporaneously. The coefficients on the diagonal normalized to unity, while the number of zero restrictions on the coefficients is 19 , so the model is overidentified.

The zero restriction is based on the assumption external variables do not contemporaneously effect by domestic variables and the ordering follow by external demand, external interest rate and external risk ${ }^{4}$. Besides that, as a small open economy, external shocks are assumed to affect domestic output gap contemporaneously. Also, domestic public debt assumed to contemporaneously affect by the external interest rate (Banerji et al., 2014; Diaz and Gemmil, 2006) and the local business cycle (Bohn, 1998).

Primary balance is assumed to be a rule with $\mathrm{FRF}^{5}$. It, therefore, responds to changes in public debt and output gap to hold fiscal sustainability and output stability, respectively. In additional, petroleum income tax and royalty are one of the major revenue of Malaysia' government. Therefore, the crude oil price assumed to affect primary balance contemporaneously.

\subsection{Data}

All data are quarterly and span the period 1996Q1-2018Q4 - the beginning of the period based on fiscal data availability in Malaysia. The data have retrieved from the Central Bank of Malaysia database (Malaysia's primary balance, real GDP and public debt), the Federal Reserve Bank of St. Louis database (3-month gross US Treasury bill rate), the IMF Primary Commodity Prices (WTI crude oil price) and the Cboe Global Markets (VIX index). All fiscal variables are in per GDP ratio while all external variables are in natural log except for the interest rate is in levels. Furthermore, all variables are seasonally adjusted using the Census X-13 methodology.

\footnotetext{
${ }^{4}$ (see Akınc1, 2013; Zaidi et al., 2014, Epstein et al., 2019; Horvath and Zhong, 2019).

5 (see Bohn,1998; De Mello, 2008; Mendoza and Ostry, 2008; Plödt \& Reicher, 2015; Baharumshah et al., 2017; Aldama and Creel, 2019).
} 
The optimal number of lags in the SVAR model combining an initial lag selection based on information criteria with an LM test for no serial correlation in the error terms ${ }^{6}$.

\section{Empirical results}

As indicated by Table 1, the forecast error variance of $Y V A R, P D$ and $P B$ at one quarter explained mainly by its shocks. At longer horizons, the index of external variables occupies $16 \%$ to $52 \%$ source of variation in FRF. On the one hand, $D^{E}$ contributes the most cause of change in FRF followed by $U^{E}$ and $R^{E}$. On the other hand, YVAR is the most insensitive variables in FRF, followed by $P B$ and $P D$. The transition effect from external shocks to output gap lower than expected, only $5 \%$ for each. Also, the respond of fiscal reaction to external shocks is weak, especially the external real interest rate. However, the external risk contributes quite significant (13\%) impact on primary balance. The public debt is the most vulnerable fiscal variables, this proportion eventually reaches more than $50 \%$, and the most prominent part comes from the crude oil price.

Table 1. Variance decomposition of FRF variables

\begin{tabular}{|c|c|c|c|c|c|c|c|}
\hline $\begin{array}{c}\text { YVAR } \\
\text { Horizon }\end{array}$ & $D^{E}$ & $R^{E}$ & $U^{E}$ & $Y V A R$ & $P D$ & $P B$ & $E F$ \\
\hline 1 & 6.56 & 0.10 & 1.01 & 92.33 & 0.00 & 0.00 & 7.67 \\
\hline 8 & 5.56 & 3.53 & 5.55 & 79.12 & 5.83 & 0.42 & 14.64 \\
\hline 16 & 5.46 & 4.15 & 5.25 & 77.87 & 6.83 & 0.44 & 14.86 \\
\hline 24 & 5.64 & 4.56 & 5.67 & 76.90 & 6.74 & 0.49 & 15.87 \\
\hline \multicolumn{8}{|l|}{$P D$} \\
\hline Horizon & $D^{E}$ & $R^{E}$ & $U^{E}$ & $Y V A R$ & $P D$ & $P B$ & $E F$ \\
\hline 1 & 1.53 & 0.92 & 0.19 & 17.12 & 80.25 & 0.00 & 2.63 \\
\hline 8 & 8.55 & 7.44 & 10.04 & 32.35 & 40.03 & 1.59 & 26.03 \\
\hline 16 & 18.68 & 9.95 & 18.21 & 20.67 & 28.59 & 3.89 & 46.84 \\
\hline 24 & 30.52 & 8.32 & 13.27 & 16.85 & 27.73 & 3.30 & 52.12 \\
\hline \multicolumn{8}{|l|}{$P B$} \\
\hline Horizon & $D^{E}$ & $R^{E}$ & $U^{E}$ & $Y V A R$ & $P D$ & $P B$ & $E F$ \\
\hline 1 & 0.00 & 0.14 & 0.07 & 6.35 & 14.34 & 79.09 & 0.22 \\
\hline 8 & 2.33 & 1.40 & 12.60 & 14.68 & 11.76 & 57.24 & 16.32 \\
\hline 16 & 4.93 & 2.21 & 12.11 & 14.68 & 11.92 & 54.15 & 19.25 \\
\hline 24 & 5.42 & 2.68 & 12.24 & 14.52 & 11.99 & 53.15 & 20.34 \\
\hline
\end{tabular}

Note: EF is external factors. Source: Author compilation.

Figures 2,3,4 depict the fiscal variables response to one standard deviation of external shocks with $95 \%$ bootstrapped confidence bands. Figure 2 shows that increased external demand implies a higher external rate and lower risk while leading to an improvement of the output gap in Malaysia. In contrast, negative responses can be observed by the public debt of Malaysia to external demand and external real interest rate shown in Figure 3. Also, public debt increase amid heightened uncertainty. On the other hands, the response of the primary balance of Malaysia to external shocks is negligible (as shown in Figure 4), and this result implies that the fiscal authority of Malaysia did not consider external shocks directly in fiscal reaction designing.

\footnotetext{
${ }^{6} \mathrm{LR}, \mathrm{FPE}$ and AIC information criteria suggest a VAR (3).
} 
Figure 2. Response of output gap to external shocks.

Response aIVAR ta Shack 1

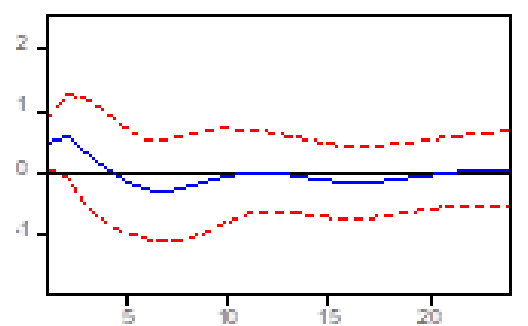

Response of WAR to Shock2

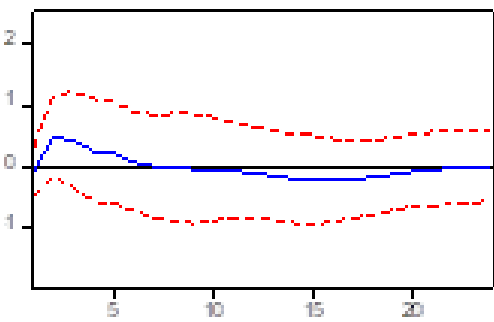

Respanse aIVNAR b Shack3

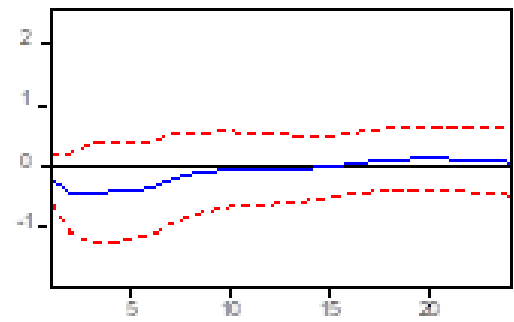

Note: Shocks 1,2,3 are crude oil price, real interest rate of US and the risk of US stock market, respectively. Areas within dashed line represent $95 \%$ bootstrap confidence bounds, computed using 10,000 repetitions. Source: Author compilation.

Figure 3. Response of public debt to external shocks.

Respanse af PD ta Shack 1

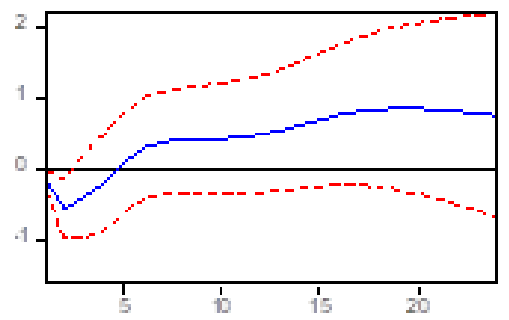

Respanse alPD b Strack2

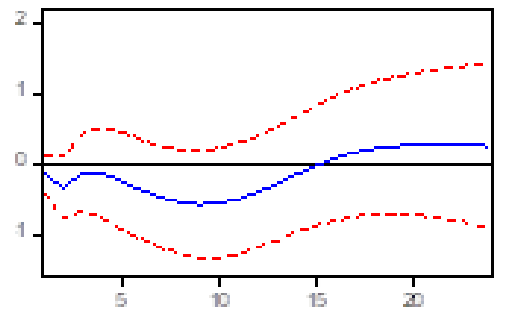

Resparise afPD ta Shack3

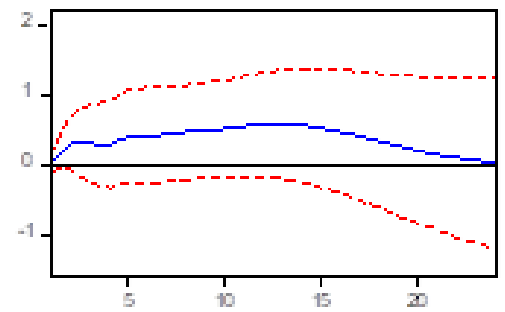

Note: Shocks 1,2,3 are crude oil price, real interest rate of US and the risk of US stock market, respectively. Areas within dashed line represent $95 \%$ bootstrap confidence bounds, computed using 10,000 repetitions. Source: Author compilation.

Figure 4. Response of primary balance to external shocks.

Resporise of PB to Sriock 1

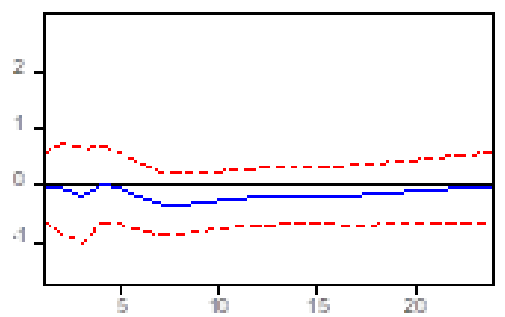

Response afPS b Srack2

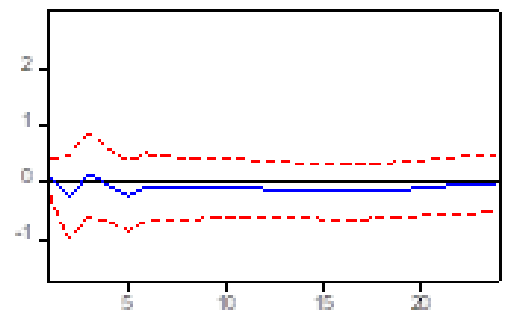

Respanse arPB la Shack 3

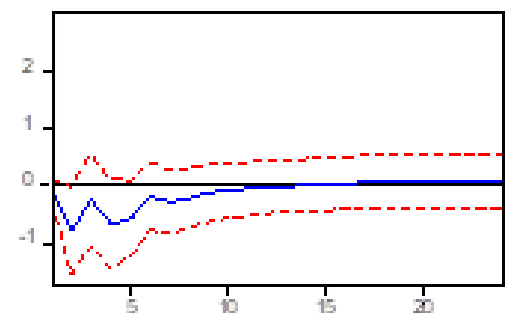

Note: Shocks 1,2,3,4,5,6 are crude oil price, real interest rate of US and the risk of US stock market, respectively. Areas within dashed line represent $95 \%$ bootstrap confidence bounds, computed using 10,000 repetitions. Source: Author compilation.

\section{Conclusion and policy implication}

This paper investigates to what extent external shocks may trigger reactions at FRF in small open economic (Malaysia). The results of SVAR confirmed external shocks magnify output gap and debt mounting. In contrast, the budgetary reaction of Malaysia to external shocks is limited. Likewise, the authority of Malaysia should respond to external shocks ingeniously in order to maintain output stabilization and fiscal sustainability.

Recent work has documented the role of monetary policy to mitigate external shocks in emerging market (Horvath and Zhong, 2019). Hence, it may be an exciting avenue for future research to examine the interaction respond of fiscal policy and monetary policy to external shocks in small open economies. 


\section{References}

Akıncı, Ö. (2013) Global financial conditions, country spreads and macroeconomic fluctuations in emerging countries, Journal of International Economics, 91(2), 358-371.

Aldama, P., and Creel, J. (2019), Fiscal policy in the US: Sustainable after all?, Economic Modelling, 81, 471-479.

Baharumshah, A. Z., Soon, S. V., and Lau, E. (2017) Fiscal sustainability in an emerging market economy: When does public debt turn bad?, Journal of Policy Modeling, 39(1), 99-113.

Banerji, S., Ventouri, A., and Wang, Z. (2014) The sovereign spread in Asian emerging economies: The significance of external versus internal factors, Economic Modelling, 36, 566-576.

Bohn, H. (1998) The behavior of US public debt and deficits, The Quarterly Journal of Economics, 113(3), 949-963.

Bohn, H. (2007) Are stationarity and cointegration restrictions really necessary for the intertemporal budget constraint?, Journal of Monetary Economics, 54(7), 1837-1847.

De Mello, L. (2008) Estimating a fiscal reaction function: the case of debt sustainability in Brazil, Applied Economics, 40(3), 271-284.

Epstein, B., Shapiro, A. F., and Gómez, A. G. (2019) Global financial risk, aggregate fluctuations, and unemployment dynamics, Journal of International Economics, 118, 351418.

Hachula, M., and Nautz, D. (2018) The dynamic impact of macroeconomic news on long-term inflation expectations, Economics Letters, 165, 39-43.

Horvath, J., and Zhong, J. (2019) Unemployment dynamics in emerging countries: Monetary policy and external shocks, Economic Modelling, 76, 31-49.

Mendoza, E. G., and Ostry, J. D. (2008) International evidence on fiscal solvency: Is fiscal policy "responsible"?, Journal of Monetary Economics, 55(6), 1081-1093.

Plödt, M., and Reicher, C. A. (2015) Estimating fiscal policy reaction functions: The role of model specification, Journal of Macroeconomics, 46, 113-128.

Weigel, D. D., and Gemmill, G. (2006) What drives credit risk in emerging markets? The roles of country fundamentals and market co-movements, Journal of International Money and Finance, 25(3), 476-502.

Uribe, M., and Yue, V.Z. (2006) Country spreads and emerging countries: Who drives whom?, Journal of International Economics, 69(1), 6-36.

Zaidi, M. A. S., Karim, Z. A., and Azman-Saini, W. N. W. (2013) Foreign and domestic shocks: Macroeconomic responses of ASEAN-3 Countries, Global Economic Review, 42(3), 215237. 